phonetically similar forms, because it was felt to be significant; Brugmann replies that the processes of phonetic change are unconscious, quite ignoring the meaning of sounds, as, in fact, we often find that phonetic decay removes letters that we know to have been originally significant.

The second principle discussed by Curtius, analogy, is one the influence of which has always been more or less acknowledged by writers on language; but it has usually been regarded as a secondary and sporadic force, leading (as the current expression 'false analogy' indicates) to malformation and confusion. The new school holds, on the contrary, that analogy is a natural, universally active force, equally prominent in the processes of forming and of learning languages. In our ordinary speaking, words present themselves to us in groups, and a new word is assigned to its most natural group, and treated accordingly. "The action of groups is, along with phonetic change, at least in our observation of accessible periods, the most important factor in the development of language " (Paul). A familiar example in English is the tendency to convert strong preterites into weak, as 'crowed' instead of the old 'crew.' The analogic process, being thus assimilative, acts in opposition to the differentiating influence of phonetic change, which more commonly tends to destroy the similarity between words. The younger philologists call in the principle of analogy to account for a number of phonetic phenomena, which the older generation of scholars either treated as unintelligible anomalies or endeavored to explain by referring them to the desire to retain significant letters, etc. Curtius objects to this wide extension of the principle, on the ground that its employment is arbitrary, and that it rests on no better basis than the admitted usage of modern languages. Brugmann rejoins that there is no reason to suppose a difference in this respect between ancient and modern languages; and Delbrück, in his 'Einleitung in das sprachstudium,' endeavors to define the character of analogical change.

The third and fourth points of Brugmann's reply to Curtius relate to questions of Indo-Germanic grammar, such as whether the primitive IndoGermanic language had not only the vowels $a, i, u$, as the older school holds, butalso $e, o$, together with diphthongs and sonant nasals and liquids, and what the origin of the inflections was. Brugmann remarks that the new philology does not absolutely avoid all glottogonic or morphogonic problems, but only those in which there are clearly not sufficient data for a solution; and whether it is worth while to attack any given problem, each man must decide for himself. Finally, in the third piece of his pamphlet, Brugmann replies to some points made by Johannes Schmidt.

The new philological school may be said to represent a more rigid adherence to law in the treatment of linquistic questions. While gratefully acknowledging the eminent services rendered to the science of language by Bopp, Grimm, Pott, Benfey, Schleicher, Curtius, and others, it claims to carry out more consistently the principles they lay down, and to fill in part the gaps they left.

C. H. Toy.

\section{CHEMICAL NOMENCLATURE.}

A COMMITTEE of fourteen chemists, including such eminent men as Williamson, Frankland, Crum Brown, Odling, and Armstrong, presented their third report on chemical nomenclature to the British association at the Aberdeen meeting. This committee was entrusted with the duty of "drawing up a statement of the varieties of chemical names which have come into use, and of indicating the causes which led to their adoption, as well as considering what can be done to bring about some convergence of the views on chemical nomenclature obtaining among English and foreign chemists."

This weighty committee produce, as might be expected, an eminently conservative report; they regard as ill advised any attempt, on etymological grounds, to change a system so firmly established as that involved in the present use of the prefixes hypo and hyper.

After confirming the terminations ic and ous, the committee considers the minor question how far the termination ous ought to be written in the forms ious and eous. The answer is: as seldom as possible ; cupreous has given way to cuprous, and 'ruthenious' and 'iridious' should also lose the superfluous $i$.

In answer to the question whether the termination ic should be employed in the names of salts of which only one class is known-as magnesic sulphate instead of magnesium sulphate, the committee says : "There is something to be claimed for both systems; and, as the diversity of practice does not lead to confusion, the question need not be regarded as vital." In our opinion, the committee might have exerted their influence to suppress the use of the unmeaning and often non-euphonious termination ic. Such terms as 'zincic' and 'nickelic' offend the ears of hearers ; 'scandic' and 'ytterbic' would be unwelcome.

The committee calls attention to the advantage of affixing the syllable $i c$ to the names of positive radicals in ethereal salts. The ambiguity arising in speaking ethyl phenylacetate, which might be taken for ethylphenyl acetate, can be obviated by 
saying ethylic phenylacetate, and ethylphenylic acetate.

It is further remarked that of late years chemists have not been sufficiently careful in applying numerical designations to substances ; thus arsenious oxide is sometimes called arsenic trioxide, although the formula of gaseous arsenious oxide is $\mathrm{As}_{4} \mathrm{O}_{6}$.

The committee considers at some length the nomenclature of acid salts, of basic salts, of sulphur salts and of double salts, pointing out some inconsistencies, suggesting some changes and proposing, very sparingly, new terms. Being the third report, many topics treated previously are not touched, and the report is consequently not very wide-reaching.

In this connection, we remark that the London chemical society, a few years ago, issued to the abstracters for its journal a series of instructions on chemical nomenclature and notation, which have been of the greatest service in securing uniformity in writing chemical language. American chemists are largely following the instructions and simple rules there laid down; and, so far as the English language is concerned, a commendable uniformity and perspicuity already obtains.

\section{H. Carrington Bolton.}

\section{POISONOUS WATERS IN THE COCOS OR KEELING ISLANDS.}

IN a recent book of travel from the pen of Henry O. Forbes of Aberdeen, Scotland, an account is given of a visit to the Cocos or Keeling Islands, which contains some new facts bearing on the history of coral islands that are specially interesting, as they supplement the studies of Charles Darwin at the same locality. The Keeling Islands, as they are usually called, are situated in the Indian Ocean about 800 miles southwest of the Straits of Sunda. They were visited by Darwin in 1836 , and by Forbes in 1878. It was while exploring these islands that Darwin's well-known hypothesis of the formation of coral reefs and atolls first suggested itself.

One of the most instructive portions of $\mathrm{Mr}$. Forbes's observations relates to the rising of poisonous waters in the lagoon enclosed by the Keeling Islands, immediately after a cyclone which occurred January 28, 1876, a description of which was furnished by Mr. G. C. Ross, the present proprietor of the islands.

On the 25th the mercurial barometer indicated some unusual atmospheric disturbance, and the air felt unusually heavy and oppressive. On the 28th

1 A naturalist's wanderings in the Eastern Archipelago. $A$ narrative of travel and exploration from 1878 to 1883 . New York, Harper, 1885 . $8^{\circ}$. it fell to close on 28 inches, a warning which gave time for all boats to be hauled to a place of safety, and other preparations for a storm to be made. On the afternoon of the same day there appeared in the western sky an ominously dark bank of clouds, and at 4 P.M. a cyclone of unwonted fury burst over that part of the Indian Ocean. About midnight on the 28th the sea rose suddenly, and rushed inland more than 150 yards from high water mark. The storm attained its greatest height about one o'clock on the morning of the 29th. At that hour no object raised a foot or two above the ground could resist its fury. The inhabitants saved themselves only by lying in hollows of the ground. To what distance the barometer might have fallen it is impossible to say, for the mercurial was carried away; two aneroids gave it at $26 \frac{1}{2}$ inches.

The following morning broke bright and calm, but not a speck of green could be seen anywhere within the compass of the islands. Round the whole atoll the solid coral conglomerate floor was scooped under, broken up and thrown in vast fragments on the beach. On the eastern shore of Home Island, Mr. Forbes observed a wall of many yards breadth, portions of which had been thrown up clear over the external high rim of the island, and several yards inward among the cocoanut trees.

About 36 hours after the cyclone the water on the eastern side of the lagoon was observed to be rising up from below of a dark color. The origin of the spring, which continued to ooze out for about ten or fourteen days, lay somewhere between the north end of New Selima and the north end of Gooseberry Island. Its color was of an inky hue, and its smell ' like that of rotten eggs.' From this point it spread southwest as far as the deep baylet in Southeast Island, where, meeting the currents flowing in at the westward and northern entrances, which run, the one round the western, the other round the eastern shore of the lagoon, its westward progress was stopped ; whereupon, turning northward through the middle of the lagoon (becoming slightly less dark as it proceeded) it debouched in the ocean by the north channel. Within twentyfour hours every fish, coral and mollusk, in the part impregnated with this discoloring substance - probably hydrosulphuric or carbonic acid-died. So great was the number of fish thrown on the beach, that it took three weeks of hard work to bury them in a vast trench dug in the sand.

At the time of Mr. Forbes's visit the islands were slowly recovering from this sad disaster. He carefully examined that part of the lagoon over which the poisoned waters flowed, and described its effect as follows : " The whole eastern half of the lagoon 